\title{
Olive mill wastewater (OMW) treatment by using ferric oxide dephenolization and chemical oxygen demand removal
}

\author{
Al-Shaweesh M. ${ }^{1}$, Matouq M. ${ }^{2}$, Al-Kabariti D. ${ }^{1}$, Khamash D. ${ }^{1}$, Al-Zawaidah S. ${ }^{3}$, Hindiyeh M. ${ }^{4}$ and Omar W. ${ }^{2}$ \\ ${ }^{1} \mathrm{Al}$-Hussein Bin Talal University, Department of Environmental Engineering, Maan, Jordan \\ ${ }^{2} \mathrm{Al}$-Balqa Applied University, Chemical Engineering Department, Amman, Jordan \\ ${ }^{3} \mathrm{Al}-$ Hussein Bin Talal University, Department of Chemistry, Maan, Jordan \\ ${ }^{4}$ Germen Jordan university, School of Natural Resources Engineering and Management, Civil and Environmental Engineering \\ Received: 27/02/2018, Accepted: 09/06/2018, Available online: 26/09/2018 \\ *to whom all correspondence should be addressed: e-mail: m.alshaweesh@ahu.edu.jo and matouq3@yahoo.com
} https://doi.org/10.30955/gnj.002650

\section{Abstract}

In Jordan and as in many other Mediterranean countries olive oil production is one of the major agricultural production, it is estimated that the annual production of olive oil in Jordan approximately 21.5 thousand tons per year. $O$ the other hand the process of olive oil extraction generates around $200,000 \mathrm{~m}^{3}$ of olive mill wastewater (OMW) and it is considered as a a serious problem in. In this study the real sample of wastewater is collected from the outlet at the mill near by the university campus. The analysis of this collected wastewater has shown a very high Chemical Oxygen Demand COD (253.648 $\mathrm{kg} \mathrm{l}^{-1}$ ) and Bilogical Oxygen Demand, BOD (89.365 $\mathrm{kg} \mathrm{l}^{-1}$ ). These high $B O D$ and $C O D$ reveals a real need to treat it before sent to municipal sewage. The study also focuses on reducing an organ phenol component which has been measured and found equal to $0.5698 \mathrm{mg} \mathrm{l}^{-1}$. The use of Ferric Oxide in the form of nanoparticles was successfully used to oxide organic phenols from olive mill wastewater (OMW) and has reduced to $0.002 \mathrm{mg} \mathrm{l}^{-1}$. The results show that $0.1 \mathrm{~g}$ of Ferric Oxide in the form of nanoparticles when mixed with sand has the capacity to remove the phenols from the collected samples. The removal percentage obtained here reached $97 \%$. When the mixture of ferric nanoparticles used with sand in a ratio of $0.1 \mathrm{~g} \mathrm{Fe}_{2} \mathrm{O}_{3}$ and $1 \mathrm{~kg}$ of sand, the removal capacity of organic phenols has reached to $99 \%$, and COD () in percentage of $97.2 \%$. The results show an interesting behavior towards other minerals that exists in solution, that ferric nanoparticles have a good capacity to remove $\mathrm{Cr}^{+3} \mathrm{Cu}^{+3} \mathrm{~K}^{+} \mathrm{Ca}^{+2} \mathrm{Na}^{+}$minerals exist in wastewater.

Keywords: Olive mill wastewater, ferric oxide, phenols, organic load removal, COD removal, sedimentationstabilization, coagulation, ferric oxide nanoparticles.

\section{Introduction}

Olive mill wastewater (OMW) contains phenolic compounds, fats and organic acids, which have a harmful effect on soil. The direct use of such water for agricultural purposes are not preferable from agriculture viewpoint and environmental. In some countries, the disposal of such wastewater even has to meet strict regulations and standards in order to discharge it to its final destination. The olive oil mill wastewater contains water (80-83\%), organic components (15-18\%) and inorganic components (2\%) mainly, potassium, sodium and phosphate (Hafizi et al., 2016). It is also reported that the effluent of OMW is acidic $(\mathrm{pH}=4-5)$ and comprises plenty of oil (Fiestas et al., 1996). Furthermore, the maximum chemical oxygen demand (COD) of olive oil wastewater can exceed $200 \mathrm{~g} \mathrm{I}^{-1}$ (Fadil et al., 2003). It has been reported that the use of biological treatment methods for this type of wastewater is difficult; due to the presence of toxic substances (Niaounakis and Halvadakis, 2006) The characteristics of this effluent prevents direct dumping to municipal wastewater treatment plants; since the effluent has a 100-200 times higher pollution load than that of urban wastewater. Jordan as other Mediterranean countries; is overwhelmed by Olive Trees, which is cultivated in huge quantities. In Jordan, olive trees are considered as an important crop for the national economy and for farmer's income. Farmers in Jordan tend to increase their cultivation of trees to increase their income and to find a new financial resource by selling its oil, as its price is also increasing which encourages farmers to take such new opportunity for extra income. There is no national strategy to study the treatment of such produced wastewater and suddenly the country finds itself to face the fact of huge quantity of olive cake waste and wastewater. The agricultural survey conducted in 2008 showed that the total area planted with olive trees in Jordan was 605 million square meter, which represents about $74 \%$ of total area planted with fruit trees (DOS, 2008) and the number has reached to 609 million square meters in 2010 (DOS, 2010). Olive production in Jordan are concentrated in two regions: the western mountain range that crosses the kingdom north-south produces $70 \%$ of the country's output, while farms in the eastern and southern part of country produce $30 \%$. The annual 
production of olive seeds considerably varies from every year; however, the average value is about 243,000 tons. The OMW consists of; water (80\%), organic matter (18\%) and minerals (2\%). This type of wastewater requires physical, chemical and biological treatment or combines between any two of these methods to remove the toxic load inside it. The typical olive oil extraction wastewater characteristics in Jordan are in Table 1. Ferric Oxide Nano particles can be employed as an alternative method for OMW treatment. Because of their relatively low cost and unique properties such as large surface area, high reactivity, high specificity, self-assembly and nanoparticles have promising perspectives for OMW treatment.

Niaounakis (2006) and Paraskeva and Diamadopoulos (2006) reported that most of the organic matter remains in the solid waste with COD commonly in the range 4-16 $\mathrm{gl}^{-1}$, in addition to inorganic compounds such as chloride, sulphate and phosphoric salts of potassium, calcium, iron, magnesium, sodium, copper and traces of other elements are also common.

OMW has been treated by several methods, biological, physico-chemical and advanced oxidation processes, electrochemical, and solar-driven and heterogeneous photocatalytic treatments. Still the unique process is not aviable although these processes are already in application the question on its economics is the only answer to adopt or discard it. In biological treatment several microorganisms as Pleurotus ostreatus, Bacillus pumilus, Phanerochaete chrysosporium, Aspergillus niger, Aspergillus terreus, Geotrichum candidum, etc. have been used (Garcia et al., 2000; Tsioulpas et al., 2002; Aggelis et al., 2003).

Advanced oxidation has a wide range of literature such as Martínez-Nieto et al. (2010), tested Fenton chemical oxidation process using ferric chloride or potassium permanganate as catalysts for the activation of $\mathrm{H}_{2} \mathrm{O}_{2}$ on an industrial scale. Kalogerakis et al. (2013) reviews the oxidation process with solvent extraction to remove pollutants compounds from waste as well a recovery process for solvent physico-chemical processes, either alone or in combination. Ayed et al has reported a review on the Advanced oxidation process and biological treatments for OMW, and they reported that advanced oxidation processes have recognized as highly efficient treatments for the degradation of organic matter, but still in general considered as expensive process while the biological processes are the most environmentally compatible and least-expensive treatment methods.

Albawab et al. (2018) has reported several treatment processes for OMW by many researchers in the Mediterranean region, using several treatment techniques to remove contaminants from OMW. These techniques include chemical, biological, physiochemical, and biophysical techniques. The treatment methods as well as the environmental impact of OMW in Jordan have summarized in their study.

The removal of biophenols from olive mill wastewater by activated carbon of different particle sizes has also studied by Senol et al. (2016), the kinetic analysis showed that the adsorption process can be approximated by a pseudo-second-order model.

Recovery of phenols from OMW was studied by Tina and Branka (2011) through comparing five sample preparation methods: filtration, solid-phase (SPE), liquid-liquid (LLE) and ultrasonic (US)-assisted extraction of liquid and solid (freeze-dried) OMWW. Their results showed that ultrasonication was a good alternative to conventional solvent extractions, providing higher recoveries at both levels of individual and total phenol yields.

This study points out the effectiveness of using Ferric Oxide nanoparticles in removing phenolic compounds from OMW and the enhancement of the sedimentationstabilization process. Study the impact of adding ferric oxide in the nano particle form on the other ions that presences in the samples such as $\mathrm{Fe}^{+3}, \mathrm{Cr}^{+3}, \mathrm{Cu}^{+3} \mathrm{~K}^{+} \mathrm{Ca}^{+2}$, and $\mathrm{Na}^{+}$

Table 1. Typical olive oil extraction wastewater characteristics in Jordan*

\begin{tabular}{|c|c|c|}
\hline Parameter & $\begin{array}{c}1993 \\
\text { Range }\end{array}$ & 2005 Range \\
\hline Total Dissolved Solids $\left(\mathrm{g} \mathrm{I}^{-1}\right)$ & $80-17$ & $2.6-6.7$ \\
\hline Total Suspended Solids $\left(\mathrm{g} \mathrm{l}^{-1}\right)$ & $14-46$ & $0.036-11$ \\
\hline $\begin{array}{l}\text { Total Fermented Suspended } \\
\text { Solids }\left(\mathrm{g} \mathrm{I}^{-1}\right)\end{array}$ & $1-14$ & $0.06-5$ \\
\hline $\begin{array}{l}\text { Total Volatile Suspended } \\
\text { Solids }\left(\mathrm{g} \mathrm{l}^{-1}\right)\end{array}$ & $7-37$ & $0.02-11$ \\
\hline Total Phosphorous $\left(\mathrm{g} \mathrm{l}^{-1}\right)$ & $0.16-0.4$ & $0.006-0.4$ \\
\hline Total Nitrogen $\left(\mathrm{g} \mathrm{l}^{-1}\right)$ & $0.4-1$ & $0.3-1.8$ \\
\hline $\mathrm{pH}(\mathrm{SU})$ & $5.48-5.91$ & $4.87-7.2$ \\
\hline $\mathrm{BOD}_{5}\left(\mathrm{~g} \mathrm{I}^{-1}\right)$ & $23-63$ & $21-83$ \\
\hline $\operatorname{COD}\left(\mathrm{g} \mathrm{l}^{-1}\right)$ & $79-16$ & $5-28$ \\
\hline $\mathrm{EC}\left(\mathrm{mS} \mathrm{cm}^{-1}\right)$ & $5-24$ & $1-11$ \\
\hline Total Phenols ( $\mathrm{g} \mathrm{l}^{-1}$ ) & $2-5.6$ & $0.3-2$ \\
\hline Fats and Oils $\left(\mathrm{g} \mathrm{l}^{-1}\right)$ & $2-13$ & $0.0020-15$ \\
\hline Total Chlorine $\left(\mathrm{g} \mathrm{l}^{-1}\right)$ & $0.5-1$ & $0.062-1$ \\
\hline Total Potassium K ( $\mathrm{g} \mathrm{l}^{-1}$ ) & $2-55$ & $0.2-8$ \\
\hline
\end{tabular}

Obtained upon a request from the Royal Scientific Society (RSS), 2017

The characteristics of wastewater as represented in Table 1, shows a high 5-Days Biological Oxygen Demands $\left(B_{5}\right)$ and Chemical Oxygen Demand (COD) content indicate a high $\mathrm{COD} / \mathrm{BOD}_{5}$, using $\mathrm{BOD}$ to indicate the organic content that will be naturally degraded and COD to indicate the organic content that will not be naturally degraded but will need further treatment. In addition to that, phenol compounds, which are toxic, are at high levels as of $11-24 \%$ of volatile solids contents.

The main problem regarding the disposal of OMW in Jordan is to find an environmentally friendly and economically feasible disposal method. Olive mills are usually associated with emissions of odorous volatile compounds. OMW causes deterioration of water bodies reflected as reflected by coloring, appearance of an oily shine, and increased Oxygen Demand (OD). It is also affecting the soil quality, which is toxic to plant life, and creates odor nuisance when disposed into the soil. 
Moreover, OMW is produced from small enterprises, which have limited financial resources and usually scattered in all regions within the country, which makes it difficult to establish a central treatment plant or disposal facility. Therefore, OMW treatment would be very expensive. On the other hand, there are indications that OMW can be beneficial and a source of wealth and income. For example, OMW can be used as a soil conditioner, biomass fuel, fertilizer and compost. OMW can also be a source of valuable products such as antioxidants, enzymes and biogas fuel. OMW contains valuable plant nutrients such as $\mathrm{N}, \mathrm{P}, \mathrm{K}$ and micronutrients as well as organic compounds that can enhance soil fertility and productivity. Some studies showed that the OMW is a phytotoxic substance to maize, it inhibits seed germination affects vigour of germination and there was a correlation between decrease in germination and phenols level in soil (Galanakis, 2016).

To avoid the expensive option of OMW treatment, Jordan has issued several provisory legislation and ministerial orders to be enforced. One of them has anticipated and allowed conditional and controlled by some measures spreading the OMW without treatment directly on land. The evidence of a high fertilizing and soil conditioning value of OMW to the soil also supported this. In addition, advanced treatment of OMW (using a series of membrane filtration starting by microfiltration, followed by ultra-filtration, nano-filtration and ending by reverse osmosis) can generate valuable by-products that can be used in cosmetic and pharmaceutical industries. It was estimated that out of $100 \mathrm{~L}$, of OMW, $68 \%$ water suitable for agricultural uses, $26 \%$ of low molecular weight products that can be used for animal feed, and $6 \%$ of hydroxytyrosol, a powerful antioxidant used in the pharmaceutical and cosmetics industries.

\section{Materials and methods}

\subsection{OMW source}

The olive mill wastewater was collected from Ma'ans governorate mill, near the campus of Al-Hussein Bin Talal University that is located in the southern part of Jordan. Table 2 illustrates the characteristic of OMW, obtained from three-phase centrifugal extraction mills. The OMW was left for a day period at room temperature before making first analysis. A control sample was kept at room temperature for comparison with fresh and treated OMW. All analyses testswere conductedin Royal Scientific Society (RSS) in Amman-Jordan. The literatures reveal that the high content of COD and BOD as in consistence with our current values (Luísa et al., 2004).

Table 2. Characteristic of OMW obtained from Máan governorate before treatment process

\begin{tabular}{cc}
\hline Parameters & Results \\
\hline $\mathrm{pH}(\mathrm{SU})$ & 4.1 \\
\hline $\operatorname{COD}\left(\mathrm{g} \mathrm{I}^{-1}\right)$ & 25 \\
\hline $\mathrm{BOD}_{5}\left(\mathrm{~g} \mathrm{l}^{-1}\right)$ & 9 \\
\hline $\mathrm{TSS}\left(\mathrm{g} \mathrm{l}^{-1}\right)$ & 10 \\
\hline $\operatorname{TDS}\left(\mathrm{g} \mathrm{l}^{-1}\right)$ & 57 \\
\hline Total Phenol $\left(\mathrm{mg} \mathrm{l}^{-1}\right)$ & 0.5698
\end{tabular}

\subsection{Procedure}

OMW after collection and after one day kept for settle down and then it has gone into three steps of pretreatment: Dilution, Coagulation-Flocculation, Filtration.

Dilution this step is used to dilute OMW with tap water; to help better and faster reactions for the steps to come. This process is very important to save time and quantities of coagulants for treatment. The best dilution rate for OMW with tap water is (1:0.5) respectively.

Coagulation-Flocculation, in this step OMW treatment, coagulation added and in which suspended, colloidal and dissolved matter are destabilized by the addition of a chemical coagulants; ferric chloride $\mathrm{FeCl}_{3}$ and lime $\mathrm{Ca}(\mathrm{OH})_{2}$ (for better coagulation). Forming insoluble precipitates like calcium oxide $\mathrm{CaO}$. Then the wastewater will separate into two phases one of them is the solid particle (sludge) and the second is black light water. The best standard quantities for ferric chloride and lime are (1:0.5) $\mathrm{mg} \mathrm{l}^{-1}$ respectively

Filtration in this step three filtration medium are chosen, sand, zeolite and activated carbon (A.C). The most important thing is the arrangement of filters. Firstly sand filter placed at the beginning because it remove most large substance, and then zeolite, which removes cations and anions, and finally activated carbon which removes odor from OMW and color. It's not only removal for these filters but the arrangement depends into these factors.

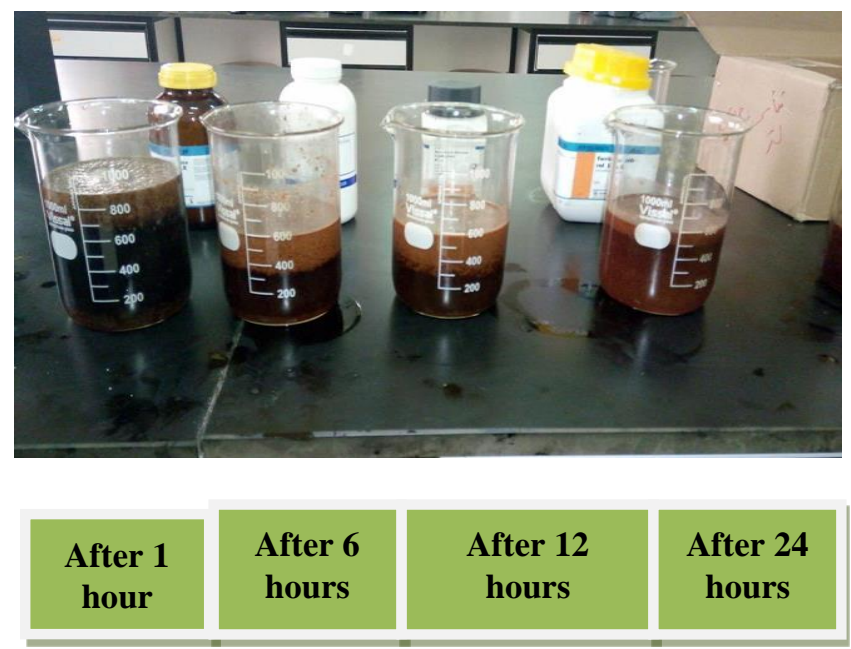

Figure 1. Sedimentation-stabilization of OMW fresh sample with time

Table 3. The characteristics of supernatant after sedimentationstabilization

\begin{tabular}{cc}
\hline Parameters & Results \\
\hline $\operatorname{COD}\left(\mathrm{g} \mathrm{l}^{-1}\right)$ & 11.9 \\
\hline $\mathrm{BOD}_{5}\left(\mathrm{~g} \mathrm{l}^{-1}\right)$ & 60 \\
\hline $\mathrm{TSS}_{\left(\mathrm{g} \mathrm{l}^{-1}\right)}$ & 462 \\
\hline TDS $\left(\mathrm{g} \mathrm{l}^{-1}\right)$ & 3.6 \\
\hline Total Phenol $\left(\mathrm{mg} \mathrm{l}^{-1}\right)$ & 0.51 \\
\hline
\end{tabular}


Table 4. Minerals concentration reduction after Ferric Oxide treatment

\begin{tabular}{ccc}
\hline Minerals & $\begin{array}{c}\text { Before Treatment } \\
\left(\mathbf{m g ~ l}^{-1}\right)\end{array}$ & $\begin{array}{c}\text { After Treatment } \\
\left(\mathbf{m g ~ l}^{-1}\right)\end{array}$ \\
\hline $\mathrm{Fe}^{+3}$ & 41.5 & 7.2 \\
\hline $\mathrm{Cr}^{+3}$ & 4.8 & 1.2 \\
\hline $\mathrm{Cu}^{+3}$ & 8.2 & 3.2 \\
\hline $\mathrm{K}^{+}$ & 1116 & 987 \\
\hline $\mathrm{Ca}^{+2}$ & 15298 & 720 \\
\hline $\mathrm{Na}^{+}$ & 5698 & 266 \\
\hline
\end{tabular}

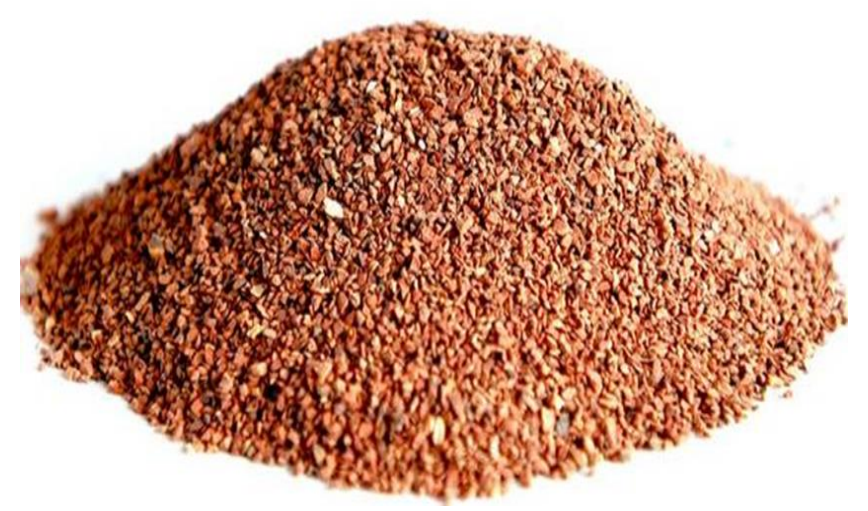

Figure 2. Mixture of sand with nanoparticles of $\mathrm{Fe}_{2} \mathrm{O}_{3}$

\section{Results and discussion}

\subsection{Sedimentation-stabilization}

The fresh OMW sample was initially completely turbid and the sludge, dirt and suspended solids were well-mixed and almost homogenous solution. Therefore, before introducing any treatment materials, the fresh OMW sample was kept stagnant for 24 hours to allow coarse and float suspended particles to settle down by gravity. It was noticed that during the first 6 hours the mixture starts to separate into two phases, at macro level. The upper layer, which is mainly the supernatant, and the lower layer, which contains sludge, dirt and suspended solids. After 18 hours, the sample was completely stable and separated into two clear layers, at macro level. Then, the two layers remained unchanged. Hence, the sedimentation time needed is concluded to be 12 hours to obtain a very clear supernatant. Figure 1 shows photographs of OMW sample taken at different time intervals. It is worth to mention here that a very thin layer of oily phase appeared on the top of the supernatant, which was skimmed off before taking the supernatant for analysis or adsorption test. After that, the supernatant was decanted and transferred for further analysis and adsorption tests. Table 3 shows the characteristics of the supernatant. It is clear that the sample characteristics have changed after sedimentation. COD value was still very high, after measuring and found to be 119658 . The reduction in the COD value by sedimentation was approximately $52 \%$. Furthermore, the reduction in the $\mathrm{BOD}_{5}$ value was approximately $32 \%$. Again, the $\mathrm{pH}$ of the supernatant is still slightly acidic which could be due to the presence of high concentration of phenolic compounds and carboxylic acids, which are categorized as weak acids.

Table 5. Analyses results of OMW after treatment process and its removal percentage for a mixture of ferric oxides nanoparticles and sand

\begin{tabular}{|c|c|c|}
\hline Parameters & Results & \% Removal \\
\hline $\mathrm{pH}(\mathrm{SU})$ & 6.5 & $\begin{array}{c}36.9 \text { (increase } \\
\text { percentage) }\end{array}$ \\
\hline $\operatorname{COD}\left(\mathrm{g} \mathrm{l}^{-1}\right)$ & 6.9 & 97.2 \\
\hline $\mathrm{BOD}_{5}\left(\mathrm{~g} \mathrm{I}^{-1}\right)$ & 8.5 & 90.53 \\
\hline TSS $\left(\mathrm{g} \mathrm{l}^{-1}\right)$ & 1.2 & 98.74 \\
\hline $\operatorname{TDS}\left(\mathrm{g} \mathrm{I}^{-1}\right)$ & 0.81 & 98.5 \\
\hline Total Phenol (mg l-1) & 0.002 & 99 \\
\hline $\mathrm{Fe}^{+3}$ & 7.2 & 79.8 \\
\hline $\mathrm{Cr}^{+3}$ & 1.2 & 71.9 \\
\hline $\mathrm{Cu}^{+3}$ & 3.2 & 54.07 \\
\hline $\mathrm{K}^{+}$ & 987 & 49.6 \\
\hline $\mathrm{Ca}^{+2}$ & 720 & 44 \\
\hline $\mathrm{Na}^{+}$ & 266 & 63.62 \\
\hline
\end{tabular}

\subsection{Ferric oxide $\left(\mathrm{Fe}_{2} \mathrm{O}_{3}\right)$ nanoparticles}

Ferric Oxide is an inorganic coagulant, which includes more than one phase that is; alpha, gamma and other phases. In this study $\mathrm{\gamma}-\mathrm{Fe}_{2} \mathrm{O}_{3}$ is used; it is ferromagnetic and has ultrafine particles smaller than 10 nanometers which are paramagnetic. Phenols and polyphenols is the coloring agent in the $\mathrm{OMW}$ and major pollutant. Ferric Oxide was used first as coagulant; $0.1 \mathrm{mg} \mathrm{I}^{-1}$, its coagulation-flocculation separation efficiency into two phases are noticed to be very weak, and the sample has homogenous characters and the removal percentage of phenols is $87 \%$. Further treatment was conducted using sand filter; and the removal percentage of phenol reached 99\%. In addition, ferric oxide has removed other minerals exist in OMW. The treatment results of using ferric oxide is given in Table 4, a clear reduction of such mineral in its concentration from original sample is significant.

\subsection{Ferric oxide $\left(\mathrm{Fe}_{2} \mathrm{O}_{3}\right)$ nanoparticles and sand}

Although the result of using ferric oxides alone as a coagulant looks good, but the idea of mixing the oxide with sand is investigated here in this study as a combination mixture and illustrated the effectiveness of using a filter of both Ferric Oxide and sand particles. Figure 2 displays a mixture of $\mathrm{Fe}_{2} \mathrm{O}_{3}$ and sand, due to good capacity of nanoparticles ferric to remove other minerals. The competitive adsorption ability of different mineral 
varies from one ion to another and is related to different factors, such as molecular mass, ion charges, hydrated ionic radius and hydration energy of the metals. This indicates that nanoparticles surface is highly attractive to a large extent of OMW contaminants and multi adsorption would occur.

The results for the mixture of ferric oxide particles and sand which was mixed in ratio of $0.1 \mathrm{~g} \mathrm{Fe}_{2} \mathrm{O}_{3}$ for every $1 \mathrm{~kg}$ sand for the removal process. The percentage of phenols removal was $99 \%$, and COD reduction reached $97.2 \%$, as given in Table 5. Figure 3 displays the results of treating OMW after using a mixture of ferric nanoparticles and sand.

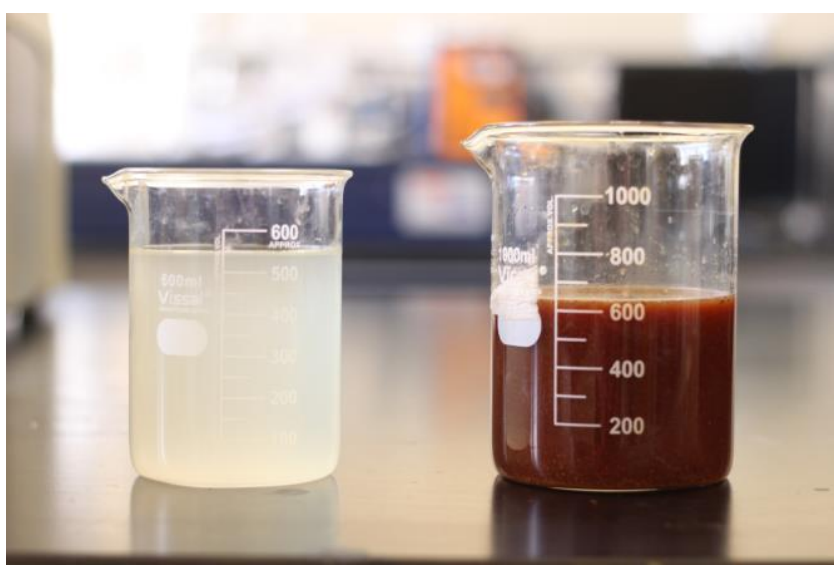

Figure 3. Treated sample after using a mixture of ferric nanoparticles and sand (left after treatment, right original sample)

\section{Conclusion}

Olive mill wastewater considered as a major environmental problem for the Mediterranean countries. Each year, millions of tons of this toxic waste are produced and most of it is not properly treated causing serious deterioration to the environment. Many treatment methods exist but the high cost prevents their application. The results showed that the $\gamma-\mathrm{Fe}_{2} \mathrm{O}_{3}$ nanoparticles were employed successfully for dephenolization and COD reduction from diluted real olive mill wastewater (OMW). The removal of mineral pollutants, by $\mathrm{Y}-\mathrm{Fe}_{2} \mathrm{O}_{3}$ nanoparticles were successfully obtained here in different degrees, such as $\mathrm{Fe}^{3+}, \mathrm{Cr}^{2+}, \mathrm{Cu}^{2+}$, $\mathrm{Ca}^{2+}, \mathrm{K}^{+}$, and $\mathrm{Na}^{+}$. This suggests that the nanoparticles have multi-adsorption sites that can accommodate different types of contaminants, which also enhances multilayer adsorption. Integrating nanoparticles adsorption with sand filtration was achieved successfully.

\section{References}

Achak M., Mandi L. and Ouazzani N. (2009), Removal of organic pollutants and nutrients from olive mill wastewater by a sand filter, Journal of Environmental Management, 90(8), 2771-2779.
Aggelis G., Iconomou D., Christou M., Bokas D., Kotzailias S., Christou G., Tsagou V. and Papanikolaou S. (2003), Phenolic removal in a model olive oil mill wastewater using Pleurotus ostreatus in bioreactor cultures and biological evaluation of the process, Water Research, 37, 3897-3904.

Al Bawab1 A., Ghannam N., Abu-Mallouh S., Bozeya A., Abu-Zurayk R., Al-Ajlouni Y., Alshawawreh F.O. and Abu-Dalo M.A. (2017), Olive mill wastewater treatment in Jordan: $A$ Review, The 2nd International Conference on Advanced Materials (ICAM-2017): Materials Science and Engineering Series 305, IOP Publishing.

Ayed L., Asses N., Chammem N., Othman N.B. and Hamdi M. (2017), Advanced oxidation process and biological treatments for table olive processing wastewaters: constraints and a novel approach to integrated recycling process: a review, Biodegradation, 28(2-3), 125-138.

Coskun T., Debik E. and Demir N.M (2010), Treatment of olive mill wastewaters by nanofiltration and reverse osmosis membranes, Desalination, 259(1-3), 65-70.

Davies L.C., André M., Vilhena J., Novais M. and Martins-Dia S. (2004), Olive mill wastewater characteristics: modelling and statistical analysis, Grasas y Aceites, 55(3), 233-241.

Fadil K., Chahlaoui A., Ouahbi A., Zaid A. and Borja R. (2003), Aerobic biodegradation and detoxification of wastewaters from the olive oil industry, International Biodeterioration \& Biodegradation, 51, 37-41.

Fiestas Ros de Ursinos J. and Borja R., (1992), Use and Treatment of Olive Mill Wastewater: Current Situation and Prospect in SPAIN, 43(2), 101-106.

Galanakis C. (2016), Olive mill waste: recent advances for sustainable management, 1st edition, Recent Advances for Sustainable Management, Academic Press.

Garcia I., Jiménez Peña P. R., Bonilla Venceslada J. L., Martín A., Martín Santos M.A. and Gómez Ramos E. (2000), Removal of phenol compounds from olive mill wastewater using Phanerochaete chrysosporium, Aspergillus niger, Aspergillus terreus and Geotrichum candidum, Process Biochemistry, 35, 751-758.

Hafizi A., Rahimpour M. R. and Hassanajili S. (2009), Olive oil mill wastewater treatment by means of electrocoaculation with punts aluminium electrodes, Revue des Sciences de l'Eau, 22(4), 473-485.

Kalogerakis N.M., Politi S., Foteinis E. and Chatzisymeon D.M. (2013), Recovery of 2 antioxidants from olive mill wastewaters: A viable solution that promotes their overall sustainable management, Journal of Environmental Management, 128, 749-758.

Martínez Nieto L., Hodaifa G., Rodríguez S. and Giménez J.A. (2010), Industrial plant for OMW from two-phase treatment by chemical oxidation, Journal of Environmental Engineering, 136, 1309-1313.

Ministry of Agriculture (MA). (2008). Department of Studies and Statistics (DOS), Amman-Jordan.

Ministry of Agriculture (MA). (2010). Department of Studies and Statistics (DOS), Amman-Jordan.

Narayan R. (2010), Use of nanomaterials in water purification. Materials Today, 13(6), 44-46.

Niaounakis M. and Halvadakis C.P. (2006), Olive Processing Waste Management Literature Review and Patent Survey, 2nd ed., Elsevier: Waste Management Series, vol. 5, pp.2364. 
Paraskeva P. and Diamadopoulos E. (2006), Technologies for olive mill wastewater (OMW) treatment: A review, Journal of Chemical Technology and Biotechnology, 81, 1475-1485.

Rusan M., Albalasmeh A. and Malkawi H. (2016), Treated olive mill wastewater effects on soil properties, Air Soil Pollution, 227, 135-145.

Senol A., Hasdemir i.M., Hasdemir B. and Kurdaş i. (2017), Adsorptive removal of biophenols from olive mill wastewaters (OMW) by activated carbon: mass transfer, equilibrium and kinetic studies., Asia-Pacific Journal of Chemical Engineering, 12, 128-146.

Tina K. and Branka V. (2011), Ultrasonic Extraction of Phenols from Olive Mill Wastewater: Comparison with Conventional Methods, Journal of Agricultural and Food Chemistry, 59(24), 12725-12731

Tsioulpas A., Dimou D., Iconomou D. and Aggelis G. (2002), Phenolic removal in olive mill wastewater by strains of Pleurotus supported in respect to their phenol oxidase (laccase) activity, Bioresource Technology, 84, 251-257.

Ugurlu M. and Kula I. (2007), Decolourization and removal of some organic compounds from olive mill wastewater by advanced oxidation processes and lime treatment Environmental Science and Pollution Research International, 14(5), 319-325.

Zobril R., Mashlan M. and Petridis D. (2002), Iron (III) oxides from thermal processes - synthesis, structural and magnetic properties, mössbauer spectroscopy characterization and applications, Chemistry of Materials, 14, 969-982. 